\title{
Oil Palm (Elaeis Guineensis Jacq.) Genetic Differences in Mineral Nutrition (Part III): Specific Leaflet Mineral Concentrations of High-Yielding Oil Palm Progenies and their Implications for Managing K And Mg Nutrition
}

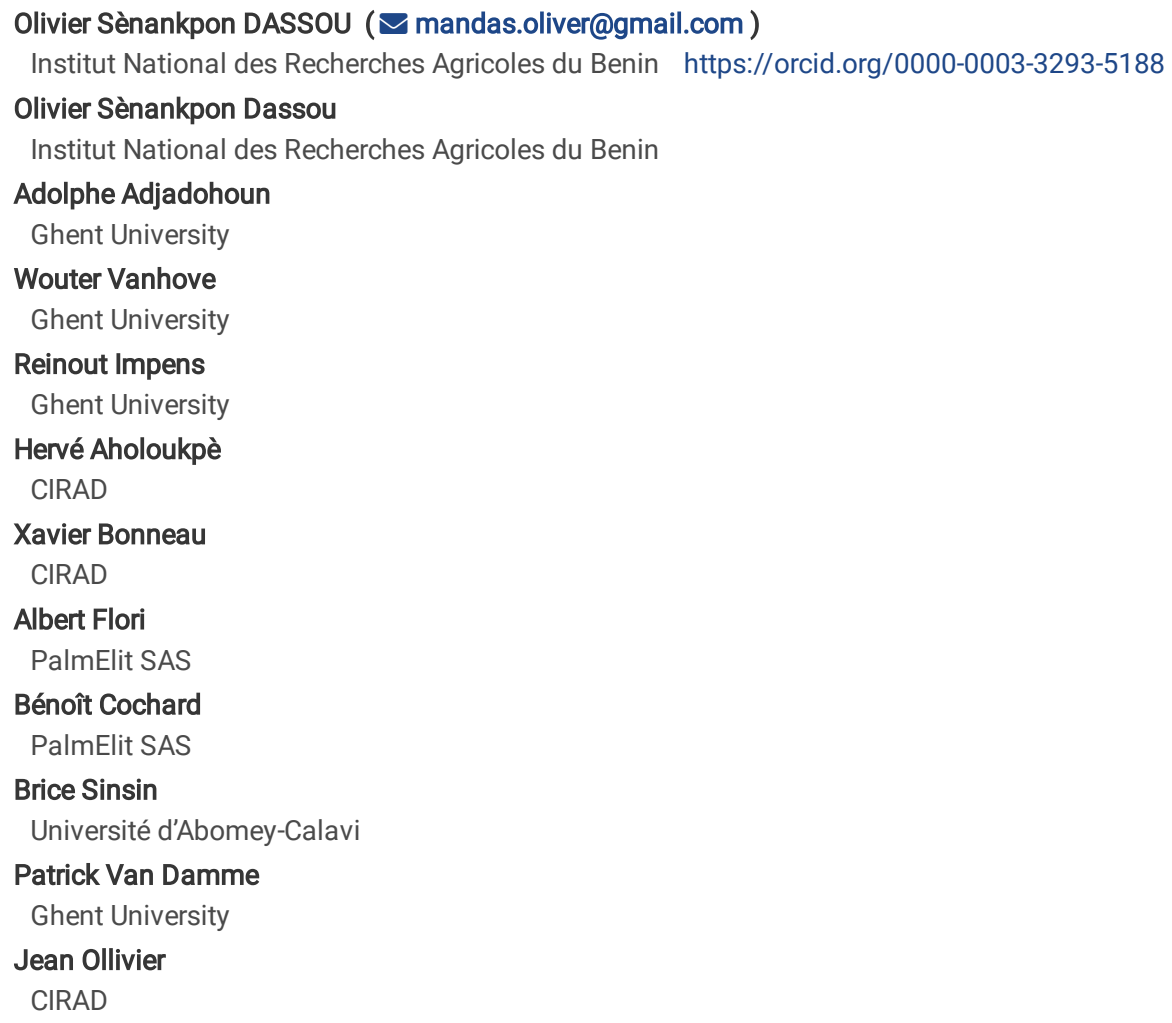

Version of Record: A version of this preprint was published at Plant and Soil on March 29th, 2022. See the published version at https://doi.org/10.1007/s11104-022-05367-8. 


\section{Abstract}

Background and aims. In oil palm, similar fertilization treatments can result in leaflet potassium and magnesium concentrations that vary significantly from one progeny to another. This hinders the development of standardized fertilizer recommendations for this crop, as they are usually calculated based on optimum leaflet nutrient concentrations.

Methods. 4-high-yielding oil palm progenies with contrasting leaflet K and Mg concentrations (C1, C2, and C3 of Delix La Mé origin and C4 of Deli x Yangambi origin) were treated with combinations of 3-levels of $\mathrm{KCl}_{\text {and }} \mathrm{MgSO}_{4}$, in a completely randomized split-plot factorial design with 6-replicates, where progenies were a sub-factor.

Results. For a given level of $\mathrm{KCl}$ or $\mathrm{MgSO}_{4}$, different leaflet $\mathrm{K}$ and $\mathrm{Mg}$ concentrations were found between progenies $(p<0.0001)$. Leaflet $\mathrm{K}$ concentration and yield response to $\mathrm{KCl}$ applications revealed that the four oil palm progenies have different optimum leaflet $\mathrm{K}$ concentrations. In our study period (5-8 YAP), progenies $\mathrm{C} 1$ and $\mathrm{C} 3$ showed their highest fresh fruit bunch (FFB) yields (13.62 and $16.54 \mathrm{t} \mathrm{ha}^{-1}$ year ${ }^{-1}$, respectively) at $\mathrm{K} 2$, whereas progenies $\mathrm{C} 2$ and $\mathrm{C} 4$ showed their highest yields (14.62 and $12.39 \mathrm{t} \mathrm{ha}^{-1}$ year $^{-1}$, respectively) at K1.

Conclusion: Our study highlighted specific optimum leaflet $\mathrm{K}$ and $\mathrm{Mg}$ concentrations for different oil palm progenies in a given environment. It paves the way for adopting $\mathrm{K}$ and $\mathrm{Mg}$ fertilizer application rates adapted to specific requirements of each type of oil palm planting material.

\section{Introduction}

Oil palm (Elaeis guineensis Jacq.) (Fam. Arecaceae) is a very productive perennial oil crop when grown under suitable pedo-climatic conditions (Tarmizi and Mohd 2006; Nodichao et al. 2008; Aholoukpè 2016). It is the high-yielding oil crop in the world (in t oil/ha) (Corley and Tinker 2016). Fresh fruit bunch (FFB) production exceeds $30 \mathrm{t} \mathrm{ha}^{-1}$ year $^{-1}$ in Southeast Asia, whereas in West Africa, production levels are often below $24 \mathrm{t} \mathrm{ha}^{-1}$ year $^{-1}$ at full maturity (Dufrène et al. 1990; Probowo et al. 2002; Nouy et al. 1999; Cros et al. 2013). In commercial plantations, high-yielding oil palm genotypes can produce $8 \mathrm{t}$ of palm oil ha ${ }^{-1}$ year $^{-1}$ under optimum conditions: rainfall $>1800 \mathrm{~mm}$ year $^{-1}$ well distributed with water deficit $<200 \mathrm{~mm}$ year ${ }^{-1}$, temperature between $25.0^{\circ} \mathrm{C}$ to $34.0^{\circ} \mathrm{C}$, and annual radiation $>12 \mathrm{MJ} \mathrm{m}^{-2} \mathrm{~d}^{-1}$, with a soil rich in organic matter (Omont 2010; Durand-Gasselin et al. 2010, 2011, Corley and Tinker, 2016). In Indonesia, palm oil yields improved from an average of $1.3 \mathrm{t} \mathrm{ha}^{-1} \mathrm{year}^{-1}$ in 1960 to $5.4 \mathrm{t} \mathrm{ha}^{-1}$ year $^{-1}$ in 2010 , half of which can be attributed to the breeding of more productive genotypes and the other half to environmental conditions (Davidson 1993; Cochard et al. 2005; Durand-Gasselin et al. 2010, 2011).

Soil fertility (i.e. the combination of soil texture, structure and mineral and organic matter) is a significant yield-determining factor in oil palm cultivation. Consequently, it is essential to apply the right types and amounts of nutrients to achieve maximum fruit bunch and oil yields.

Potassium (K) plays a role in physiological processes, such as stomatal opening and closure, along with $\mathrm{CO}_{2}$-assimilation by enabling the transformation of light into chemical energy during photosynthesis (Yanbo et al. 2008). $\mathrm{K}$ is also the main driver of oil palm vegetative growth and fruit and oil production, due to its role in chlorophyll fluorescence emission (Yanbo et al. 2008). K is further involved in transporting sugar assimilates from photosynthetic tissues to other organs of the plant (Lamade et al. 2014), such as inflorescences and developing fruits. Applying K to oil palms, seeing its soil content, usually increases their leaflet $\mathrm{K}$ concentrations (Dubos et al. 2017), number of functional fronds (i.e. non-senescent), number of inflorescences and fruit bunch weight (Kusnu et al. 1996). According to Corley and Tinker (2016), K application increases overall oil palm dry matter production and oil yield. Oil palm leaflet $\mathrm{K}$ concentration is a good yield indicator (Goh et al. 1999). It is therefore used as a basis for the calculation of the amount of K fertilization required to maximize oil palm yield. Under Nigerian environmental conditions, with 2066 mm of average rainfall year-1 (Bonneau et al. 2014), mature commercial oil palms that yield between 133 and $148 \mathrm{~kg}$ of FFB palm ${ }^{-1}$ year ${ }^{-1}$ have been found to require up to $2.5 \mathrm{~kg} \mathrm{KCl} \mathrm{palm}^{-1}$ year $^{-1}$ (Bonneau et al. 2018).

Magnesium also plays essential and specific roles in oil palm metabolism. As the central element of the chlorophyll molecule, Mg enhances photosynthesis and is also involved in enzymatic reactions related to energy transfer (Gerendás and Führs 2013). However, there are indications that oil palm's leaflet mineral concentrations can vary greatly from one progeny to another, suggesting that mineral requirements depend on the vegetal material (Jacquemard et al. 2010 : Prabowo et al. 2012; Ollivier et al. 2017).

Leaf analysis is a commonly used agronomic tool for assessing oil palm mineral requirements, hence for determining the right amounts of fertilizers to be applied (Dubos et al., 2019). Factorial trials can provide useful data for developing fertilizer $\mathrm{x}$ yield response curves and for determining optimum mineral concentrations in oil palm leaflets that are linked to the best economic yields (Webb 2009). To that end, fertilizer recommendations are made by comparing the actual nutrient concentrations in oil palm leaflets with optimum nutrient levels, as determined by fertilizer $\mathrm{x}$ yield response curves (Dubos et al. 2010).

Environmental conditions affect leaflet $\mathrm{K}$ and Mg dynamics in oil palm progenies (Doğan and Akinci, 2011; Ciríaco da Silva et al., 2011). Studies in Indonesia and Nigeria have revealed significant variations in leaflet potassium $(\mathrm{K})$ and magnesium $(\mathrm{Mg})$ concentrations for different oil palm progenies (Ollivier et al. 2013, 2017; Lee et al. 2014; Dassou et al., 2018) producing similar oil yields and receiving equal amounts of fertilizers (Ollivier et al. 2017). Such variation hampers the unequivocal conversion of leaflet nutrient concentrations into standardized fertilizer recommendations for all commercially used oil palm genotypes. Consequently, there is a need for deeper knowledge of interactions between oil palm genetic materials (GM) and mineral nutrition (MN).

In this study, we assess how different oil palm progenies react when subjected to different combinations of potassium and magnesium fertilizer rates. We hypothesize that in a given environment, different oil palm progenies have different fertilizer $\mathrm{x}$ yield response curves and therefore different optimum leaflet $\mathrm{K}$ and $\mathrm{Mg}$ concentrations. The results of this study should help to identify progenies that require less fertilizer to obtain a given oil palm bunch and oil production levels in the specific agroclimatic environment of Nigeria (West Africa), which could reduce fertilizer costs in the Nigerian oil palm sector. Providing 
oil palm growers with more productive planting material that requires fewer fertilizers can increase the ecological and economic sustainability of global oil palm cultivation.

\section{Materials And Methods}

\subsection{Experimental site characteristics}

The trial was set up at Ologbo (Presco Plc oil palm plantation) near Benin City (N6.03652 ${ }^{\circ}$ E $5.55609^{\circ}$ at $20 \mathrm{~m}$ a.s.l) in Nigeria. Average annual rainfall in the study area between 1996 and 2018 was 2,066 mm (Bonneau et al. 2014). Rainfall distribution is monomodal, with a dry season from November to March, and a rainy season from April to October (Bonneau et al., 2014). According to the latter author, it is highly unlikely that oil palms suffer from drought in this area, unless an exceptional dry period occurs. Unfortunately, the El Niño phenomenon resulted in more than five months of unusual drought with only $338.7 \mathrm{~mm}$ total precipitation between November 2015 and March 2016. In the same period (November to March), between 1996 and 2018 , average annual temperatures ranged from $25.0^{\circ} \mathrm{C}$ to $27.8^{\circ} \mathrm{C}$, and average annual radiation was $13.78 \mathrm{MJ} \mathrm{m}^{-2} \mathrm{~d}^{-1}$. The ferralsols (FOA nomenclature) have a flat relief, are uniform, deep and very sandy on the surface, with a gradual increase in clay contents with depth. Soil fertility was low (Supplementary table ST1).

\subsection{Plant material}

Four different Tenera oil palm (Elaeis guineensis Jacq.) progenies (C1, C2 and C3 of Deli x La Mé origin, and C4 of Deli x Yangambi origin) were selected for this study (Supplementary table ST2). In an earlier experiment (oil palm genetic trial) in Indonesia (Ollivier et al. 2017), under a given fertilization regime, these progenies showed the most contrasting leaflet $\mathrm{K}$ and $\mathrm{Mg}$ concentrations among a population of 116 progenies, with high and similar fresh fruit bunches (FFB) and oil yields. These progenies represent a wide genetic diversity of the E. guineensis species. Their contrasts in leaflet $\mathrm{K}$ and $\mathrm{Mg}$ concentrations covered the extreme ranges of leaflet concentrations in these minerals (PIC 2011).

\subsection{Fertilizer treatments}

During the 8-year trial period (2011-2019), the four oil palm progenies were treated with potassium chloride $\left(\mathrm{KCl} \mathbf{6 0} \% \mathrm{~K}_{2} \mathrm{O}\right)$ and kieserite $\left(\mathrm{MgSO}_{4}: 27 \% \mathrm{MgO}\right)$ fertilizers according to all possible combinations of three levels (0-1-2) of each fertilizer (Supplementary table ST3).

In the first year after planting (YAP), fertilizers were applied as a basal and uniform top dressing. A basic application of urea (1000 $\mathrm{g}$ palm $\left.{ }^{-1}\right)$ and triple superphosphate $\left(500 \mathrm{~g} \mathrm{palm}^{-1}\right)$ was applied in the second year. Additional combinations of $\mathrm{KCl}$ and $\mathrm{MgSO}_{4}$ fertilizer rates were applied for seven years, by increasing their amounts each year in the main fertilizer plots, starting from year two (Supplementary table ST3).

Starting from 4 YAP, a fixed fertilizer rate of $0,1.5$ and $3.0 \mathrm{~kg} \mathrm{palm}^{-1} \mathrm{year}^{-1}$ of $\mathrm{KCl}$ for $\mathrm{KO}, \mathrm{K}$ and $\mathrm{K} 2$, respectively, and of $0,0.75{\text { and } 1.5 \mathrm{~kg} \text { palm }}^{-1}$ year ${ }^{-1}$ of kieserite for $\mathrm{MgO}, \mathrm{Mg} 1$ and $\mathrm{Mg}$ 2, respectively, were applied. Over the eight years of fertilization, the cumulative $\mathrm{KCl}$ applied per palm amounted to 0,9 and 18 $\mathrm{kg} \mathrm{palm}^{-1}$ for $\mathrm{K0}, \mathrm{K} 1$ and $\mathrm{K} 2$ respectively, whereas the cumulative $\mathrm{MgSO}_{4}$ applied per palm amounted to $0,3.7$ and $7.4 \mathrm{~kg} \mathrm{palm}{ }^{-1}$ for Mg0, Mg1 and Mg2, respectively. Leaf analysis revealed a chlorine (Cl) deficiency in the K0 plots, which might have limited K uptake (Dubos et al. 2010). Chlorine was applied as $\mathrm{NaCl}$ to all palms in the $\mathrm{KO}$ plots until leaflet $\mathrm{Cl}$ concentrations reached the required level of $0.5 \%$ of dry matter (DM), to avoid a chlorine deficiency, while $\mathrm{Na}$ concentrations remained very low (0.005\% DM on average) with no visual toxicity effects in the field. The progenies also displayed deficient leaflet boron (B) concentrations in all plots, which were resolved by applying borax $\left(\mathrm{B}_{2} \mathrm{O}_{3}\right)$ at a rate of $100 \mathrm{~g} \mathrm{palm}^{-1}$ in the first 4 YAP (split into $10 \mathrm{~g}$ palm ${ }^{-1}$ in the first year, $20 \mathrm{~g}$ palm ${ }^{-1}$ in the following two years and $50 \mathrm{~g} \mathrm{palm}^{-1}$ in the fourth YAP), applied to all palms in the trial to prevent a boron deficiency.

\subsection{Experimental design}

The trial, consisted of a $\mathrm{K}^{3} \mathrm{Mg}^{3}$ factorial split plot design (Supplementary fig. SF1), which was set up in 2011 on 33 ha with palms planted 9 m apart in a staggered, equilateral triangle design corresponding to a planting density of 143 plants ha ${ }^{-1}$ (PIC, 2012). Measurements were carried out over 6 years (2013 to 2019). All combinations of three levels of potassium chloride $\left(\mathrm{KCl}: 60 \% \mathrm{~K}_{2} \mathrm{O}\right)$ and kieserite $\left(\mathrm{MgSO}_{4}: 27 \% \mathrm{MgO}\right)$ fertilizers were tested, resulting in a total of nine completely randomized fertilizer treatments. Each fertilizer treatment was applied to 4 subplots, each planted with one of the four oil palm progenies and in three rows of three palms. The experimental trial layout comprised six replicates (i.e. 36 subplots per replicate, 216 subplots in total and 1944 palms in the trial as a whole). The studied palms in each subplot were surrounded by border palms in all directions ( 45 border palms per fertilizer plot, i.e. a total of 2,430 border palms for all 54 fertilized plots). Another 350 border palms were planted along the sides of the road to protect the palms under study and their main border palms from attacks by rodents, as the trial is located near a forest.

\subsection{Measured parameters}

\subsubsection{Fresh Fruit Bunch (FFB) and male inflorescence production}

Each month from 2013 (first year of FFB production) to 2019 (3 to 8 YAP), three harvesting rounds were organized to collect ripe bunches. Bunch number and bunch weight of each individual palm were recorded on each harvesting round. Three yield components were considered for each YAP: number of bunches per palm, average bunch weight per palm and total bunch weight per palm. Yield data were summed on a monthly and annual basis. Annual production in $t$ ha ${ }^{-1}$ was obtained by multiplying the total production obtained for one year (in tons) by 135 palms, rather than the actual 143 palms per ha (planting density of industrial plantations), following Durand-Gasselin et al. (2006). The latter deduction of 8 palms per ha accounted for non-productive palms (dead and abnormal palms estimated to be 4 palms per hectare on the basis of a phytosanitary census, Durand-Gasselin et al. (2006)) and areas occupied by roads in plantations (also estimated to amount to 4 palms per hectare). The production is calculated on the basis of 135 palms per hectare to represent yield that could be achieved in an industrial plantation with the same treatments. 
Male inflorescences were counted on a monthly basis by painting the petiole of all fronds holding a male inflorescence. Different paint colours were used for successive months to avoid mistakes in the inflorescences counting. This allowed us to distinguish fronds bearing male from those bearing female inflorescences even if the male inflorescence had completed its growth cycle and was abscised or when the bunches resulting from the female inflorescences had been harvested.

\subsubsection{Bunch analysis: oil extraction rate (OER) and crude palm oil (CPO) production}

Five years after planting, bunches were analysed following the CIRAD bunch analysis protocol (IRHO-CIRAD-IGK 9, 1996) to assess the oil extraction rate (OER). For each progeny subplot, 40 bunches were randomly selected and analysed over two years at weekly intervals (resulting in 960 analysed bunches: 40 bunches $x 4$ progenies $x 6$ replicates). Progeny OER values were averaged over all 6 replicates. To obtain the industrial oil extraction rate (OER $\left.\mathrm{mill}_{1}\right)$, the laboratory oil extraction rate $\left(\mathrm{OER}_{\mathrm{Lab}}\right)$ was multiplied by 0.855 to account for losses (as a result of inefficient extractors), as per Durand-Gasselin et al. (2006). Total bunch weights per palm were subsequently multiplied by their respective OER to obtain their crude palm oil (CPO) production.

\subsubsection{Optimum leaflet $\mathrm{K}$ and $\mathrm{Mg}$ concentration levels}

Progenies' leaflet mineral ( $\mathrm{K}$ and $\mathrm{Mg}$ ) concentrations were assessed each year in December. From each of the nine central useful palm trees in each subplot, 3 leaflets were sampled on each side (left and right) at the middle of the leaf rachis of rank 17 (Ollivier et al. 2017). Leaflet samples were dried in an oven at $80^{\circ} \mathrm{C}$ for at least 48 hours (CIGE 2013). K, Mg and Ca concentrations were analyzed using the standard CIRAD laboratory protocol for plant tissue analysis (CIRAD, US 49, France), which uses inductive coupled plasma-optical emission spectrometry (Model: ICP-OES Agilent 720-ES) after double calcination extraction following Pinta (1973), Doğan and Akinci (2011) and Ciríaco da Silva et al. (2011). Optimum leaflet mineral concentrations were determined using leaflet mineral concentration and yield response curves. Optimum leaflet mineral concentrations correspond to the maximum yield obtained in response to a fertilization level beyond which additional fertilizer application does not add extra yield (Ochs 1985). It is therefore possible that an optimum leaflet mineral concentration is lower than the maximum leaflet mineral concentration.

\subsection{Statistical analysis}

To examine genotype, fertilizer and genotype x fertilizer interaction effects, three-way ANOVAs were performed with the factors "genotype", "K" and "Mg". The split-plot nature of the design was taken into account by conducting the ANOVAs using a mixed effects model, with the sub-block effects (i.e. fertilizer $x$ block interaction) as a random factor. Tukey's multiple comparison test was run to evaluate the significance of differences in parameter means between progenies and between K-Mg fertilization level combinations.

Linearity of the response curves was tested with a quadratic contrast test. Statistical analyses were performed using software packages XLSAT, (Version 2018-7, www.xlstat.com) and R version R-3.6.0 of Windows, 32/64 bit.

\section{Results}

\subsection{Effect of $\mathrm{KCl}$ and $\mathrm{MgSO}_{4}$ fertilization on leaflet $\mathrm{K}$ and $\mathrm{Mg}$ concentrations}

Progenies displayed different leaflet $\mathrm{K}$ concentrations in response to the applied $\mathrm{KCl}$ levels. Treatment $\mathrm{K} 1$ significantly $(p<0.0001)$ increased leaflet $\mathrm{K}$ concentrations in the palms of progenies $\mathrm{C} 1, \mathrm{C} 2$ and $\mathrm{C} 3$ compared to treatment $\mathrm{K} 0$, whereas no significant differences were observed in leaflet $\mathrm{K}$ concentrations between oil palms with treatment $\mathrm{K} 2$ compared to the palms with treatment $\mathrm{K} 1$ in the same progenies. Leaflet $\mathrm{K}$ concentrations of progeny $\mathrm{C} 4$ significantly increased between treatments $\mathrm{K} 0$ and $\mathrm{K} 1$ and between treatments $\mathrm{K} 1$ and $\mathrm{K} 2$. With data pooled for all progenies, average leaflet $\mathrm{K}$ concentrations significantly increased from $0.715-0.829 \%$ and $0.864 \%$ of DM for K0, K1 and K2, respectively (Fig. 1A).

Without $\mathrm{KCl}$ application (KO) over the same period ( 5 to $7 \mathrm{YAP}$ ), progeny $\mathrm{C} 4$ had a leaflet $\mathrm{K}$ concentration $(0.82 \%)$ that was $11 \%, 18 \%$ and $25 \%$ higher than in progenies $\mathrm{C} 1, \mathrm{C} 2$ and $\mathrm{C} 3$, respectively. Respective increases were $12 \%, 18 \%$ and $24 \%$, for treatment $\mathrm{K} 1$ and $11 \%, 20 \%$ and $26 \%$ for treatment $\mathrm{K} 2$ (Fig. $1 \mathrm{~A}$ ).

$\mathrm{MgSO}_{4}$ applications (data pooled for all progenies) had a significant effect $(p=0.0002)$ on leaflet $\mathrm{Mg}$ concentrations. Across all progenies, average leaflet $\mathrm{Mg}$ concentrations in oil palms with treatment Mg2 $(0.288 \%$ of DM) differed significantly $(p=0.0002)$ from those with treatment Mg1 $(0.270 \%$ of $\mathrm{DM})$ and those with treatment $\mathrm{MgO}(0.263 \%$ of DM), with the last two concentrations not significantly differing from one another (Fig. 1B).

With treatment $\mathrm{Mg0}$, the palms of progeny $\mathrm{C} 3$ had a leaflet $\mathrm{Mg}$ concentration $(0.292 \%)$ that was $13 \%, 18 \%$ and $10 \%$ higher than that of the palms of progenies C1, C2 and C4, respectively. Respective increases were $12 \%, 18 \%$, and $13 \%$, for treatment Mg1 and 13\%, 16\%, and $10 \%$, for treatment Mg2, respectively (Fig. 1B).

Average leaflet $\mathrm{Mg}$ concentrations significantly $(p=0.002)$ decreased from $0.302-0.266 \%$ and 0.255 of $\mathrm{DM}$, for treatments $\mathrm{K} 0, \mathrm{~K} 1$ and $\mathrm{K} 2$, respectively. However, in all progenies there were no significant differences in leaflet $\mathrm{Mg}$ concentrations between treatments $\mathrm{K} 1$ and $\mathrm{K} 2$. Leaflet Mg concentrations decreased in all progenies from K0 to K1, whereas there was no significant difference between treatments $\mathrm{K} 1$ and $\mathrm{K} 2$ for none of the progenies (Fig. 1C).

Increasing $\mathrm{MgSO}_{4}$ levels had no significant effect on leaflet $\mathrm{K}$ concentrations in the progenies. However, leaflet $\mathrm{K}$ concentrations differed between progenies for each Mg level (Fig. 1D). Statistical analysis did not reveal any significant $\mathrm{K}^{\star} \mathrm{Mg}$ interactions for leaflet $\mathrm{K}$ or $\mathrm{Mg}$ concentrations.

\subsection{Influence of $\mathrm{KCl}$ fertilization on oil palm progeny yield components}

Progeny $\mathrm{C} 1$ produced the largest number of bunches per year $(14.4 \pm 6.0)$, which was not statistically different from those of progeny $\mathrm{C} 2$ (14.3 \pm 5.1$)$. The palms of progeny $\mathrm{C} 4$ produced the lowest annual bunch number $(11.4 \pm 2.5)$, which was significantly lower than that of progenies $\mathrm{C} 1$ and $\mathrm{C} 2$, whereas

Page $4 / 13$ 
progeny C3 palms had an intermediate average annual bunch number (13.6 \pm 5.3$)$, which significantly differed from that of progenies C1, C2 and C4 (Table 1).

The number of male inflorescences significantly $(\mathrm{p}<0.0001)$ differed between progenies. Progeny $\mathrm{C} 1$ (Delix La Mé origin) exhibited the lowest annual number of male inflorescences $(6.8 \pm 4.3)$. Progenies $\mathrm{C} 2$ and $\mathrm{C} 3$ had intermediate male inflorescence numbers $(9.1 \pm 4.6$ and $9.5 \pm 4.4)$, whereas progeny $\mathrm{C} 4$ produced the largest number of male inflorescences $(15.3 \pm 3)$.

The "bunch number to emitted frond number" ratio was $0.40,0.37,0.36$ and 0.31 in the palms of progenies $\mathrm{C} 1, \mathrm{C} 2, \mathrm{C} 3$ and $\mathrm{C} 4$, respectively.

Progeny C3 palms had the highest average bunch weight $\left(8.9 \pm 2.8 \mathrm{~kg}_{\text {bunch }}^{-1}\right)$ over the 5 to 8 YAP period and an average weight of 10.7 and $11.9 \mathrm{~kg}^{\mathrm{bunch}}{ }^{-1}$ at the age of 7 and 8 YAP (last two years of bunch harvesting), respectively (Table 1). On average, the palms of progenies $\mathrm{C} 1$ and $\mathrm{C} 2$ produced the lightest bunches, with bunch weights for progeny $\mathrm{C} 1$ that were significantly lower than those of progeny $\mathrm{C} 2\left(7.3 \pm 1.8\right.$ and $7.7 \pm 2.4 \mathrm{~kg}$ bunch ${ }^{-1}$, respectively). Average bunch weight for progeny C4 palms at 8 YAP $\left(11.8 \mathrm{~kg} \mathrm{bunch}^{-1}\right)$ was similar to that of progeny $\mathrm{C} 3$ at the same age. However, at 7 YAP, the palms of progeny $\mathrm{C} 4$ had an average bunch weight of $8.07 \mathrm{~kg}$, which was significantly lower than that of progeny $\mathrm{C} 3$ at the same age.

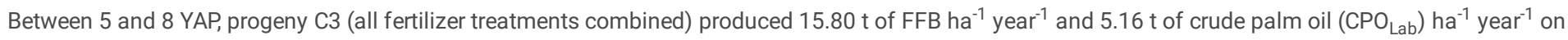
average (Table 2), which was significantly higher than the $\mathrm{FFB}$ and $\mathrm{CPO}_{\mathrm{Lab}}$ of the palms of the other progenies, particularly those of progeny $\mathrm{C4}$, which produced the lowest average yield (12.20 $\mathrm{t}_{\text {f }} \mathrm{FFB} \mathrm{ha-1} \mathrm{year}^{-1}$ and $3.78 \mathrm{t}$ of $\mathrm{CPO}_{\mathrm{Lab}}$ ) ha ${ }^{-1}$ year ${ }^{-1}$. The highest bunch producing progenies $(\mathrm{C} 3>\mathrm{C} 2)$ were also the highest oil producers, with similar oil extraction rates (Table 2). The lowest oil extraction rate (OER $\mathrm{Lab}_{\mathrm{b}}$ : $\left.31.65 \%\right)$ was found for progeny $\mathrm{C} 4$, whereas progenies $\mathrm{C} 2$ and $\mathrm{C} 3$ had significantly higher extraction rates (32.46\% and $32.74 \%$, respectively). No $\mathrm{KCl}$ effect on the oil extraction rate was observed for any progeny ( $p$ $=0.19)$.

$\mathrm{KCl}$ treatments were associated with bunch weight increases for the palms of progenies $\mathrm{C} 2(+0.6 \mathrm{~kg}$ from $\mathrm{K} 0$ to $\mathrm{K} 1 ; p=0.017), \mathrm{C} 3(+0.8 \mathrm{~kg}$ from $\mathrm{K} 0$ to $\mathrm{K} 2 ; p=$ $0.0001)$ and $\mathrm{C} 4(+1.0 \mathrm{~kg}$ from K0 to $\mathrm{K} 1 ; p<0.0001)$ and bunch number increases for the palms of progeny $\mathrm{C} 1$ (+0.7 bunches year ${ }^{-1}$ from $\mathrm{K} 0$ to $\left.\mathrm{K}_{2}\right)$ with a significant linear contrast test result $(\mathrm{F}=4.37 ; p=0.038)$ over the 5 to 8 YAP period.

In none of the progenies did $\mathrm{KCl}$ applications have a significant effect on the average number of male inflorescences produced per palm, except at 5,6 and 7 YAP for progenies C4, C2 and C3, respectively (Table 1).

The linear contrast test on the average bunch weight for the $\mathrm{KCl}$ treatment of progeny $\mathrm{C} 3$ was significant $(\mathrm{F}=19.7 ; p<0.0001)$. The quadratic contrast test was significant $(\mathrm{F}=10.0 ; p=0.002)$ for progeny $\mathrm{C} 4$, but not for progeny $\mathrm{C} 2(\mathrm{~F}=3.2 ; p=0.074)$.

\subsection{Yield responses to $\mathrm{KCl}$ applications}

Over the 5 to 8 YAP period, we found significant $(p<0.0000)$ differences in bunch production between progenies. For all $\mathrm{KCl}$ levels applied, annual bunch production per palm could be ranked as $\mathrm{C} 3>\mathrm{C} 2>\mathrm{C} 1>\mathrm{C} 4$ (Fig. 2), with a difference of 25 to $30 \mathrm{~kg} \mathrm{palm}^{-1}$ year ${ }^{-1}$ between the highest (C3) and the lowest yielding progeny (C4).

In all progenies, bunch production was significantly lower for treatment K0 than for treatments K1 and K2. Treatment K1 significantly improved bunch yields for the palms of all progenies ( $p=0.0007)$ compared to treatment K0. For progenies C2 $(p=0.037)$ and C4 $(p=0.015)$, there was a significant increase in bunch production only between treatments K0 and K1 (Fig. 2). For progenies C1 $(p=0.045)$ and C3 $(p=0.003)$, significant increases in bunch production gains were also observed between oil palms receiving treatments $\mathrm{K} 1$ and $\mathrm{K} 2$.

\subsection{Progenies' optimum K levels}

The quadratic contrast test results $(\mathrm{F}=2.56 ; p=0.111$ and $\mathrm{F}=3.11 ; p=0.079$, for $\mathrm{C} 2$ and $\mathrm{C} 4$, respectively) were not significant, indicating that $\mathrm{K} 1$ was the optimum level for these two progenies (Fig. 3). Leaflet K concentrations of palms with the $\mathrm{K} 1$ treatment were $0.78 \%$ and $0.95 \%$ for progenies $\mathrm{C} 2$ and $\mathrm{C} 4$, respectively.

For progenies $\mathrm{C} 1$ and $\mathrm{C} 3$, maximum yield was only reached with treatment $\mathrm{K} 2$ (Fig. 3). The contrast test results showed $\mathrm{KCl}$ response linearity $(\mathrm{F}=6.16 ; p=$ 0.014 and $\mathrm{F}=11.8 ; p=0.000$ for $\mathrm{C} 1$ and $\mathrm{C} 3$ respectively), indicating that in our experiment, $\mathrm{K} 2$ was the optimum $\mathrm{KCl}$ treatment for progenies $\mathrm{C} 1$ and $\mathrm{C} 3$ (Fig. 3). Leaflet $\mathrm{K}$ concentrations at $\mathrm{K} 2$ were $0.91 \%$ and $0.77 \%$ for progenies $\mathrm{C} 1$ and $\mathrm{C} 3$, respectively.

$\mathrm{MgSO}_{4}$ had no effect on the yield of any progeny, except for the average bunch weight of progeny C3 over the 5 to 8 YAP period $(p=0.049)$, with an increase of $0.35 \mathrm{~kg}$ bunch $^{-1}$ between treatments $\mathrm{Mg0}$ and $\mathrm{Mg} 1$.

\section{Discussion}

\subsection{Oil palm progeny (optimum) leaflet mineral concentrations}

Leaf analysis remains the most frequently used tool for predicting oil palms' mineral requirements. It allows to tailor fertilizer applications to specific oil palm genotypes when cultivated in a specific environment (Dubos et al. 2019).

We showed that oil palms of different progenies had specific optimum leaflet $\mathrm{K}$ levels in our experiment in the Nigerian growth conditions. The leaflet Mg concentrations corresponding to optimum leaflet $\mathrm{K}$ levels were found to be $0.227 \%, 0.224 \%, 0.264 \%$ and $0.236 \%$ of DM for progenies $\mathrm{C} 1, \mathrm{C} 2$, C3 and $\mathrm{C} 4$, respectively. 
The fact that different progenies have different optimum leaflet $\mathrm{K}$ concentrations specific $\mathrm{KCl}$ fertilization rates is most likely linked to progeny-specific leaflet $\mathrm{K}$ allocation and/or progeny-specific $\mathrm{K}$ uptake. The different progeny-specific optimum $\mathrm{KCl}$ levels might imply that each progeny has its specific $\mathrm{K}$ requirement.

The linearity $\mathrm{KCl}$ response showed by the contrast test results in our study (Fig. 3) for progeny $\mathrm{C} 1$ and $\mathrm{C} 3$ implies that the latter progenies may request a higher $\mathrm{KCl}$ amount than that supplied with $\mathrm{K} 2$.

The fact that oil palms of different progenies exhibit different yields for a given $\mathrm{KCl}$ application rate could also mean that these progenies may be more or less efficient in using the amounts of $\mathrm{K}$ taken up. These hypotheses should be further explored. However, after being equally fertilized, progenies have shown significant differences in leaflet mineral concentrations, which could be related to the differential partitioning of the minerals in the palm tissues that implies that for the assessment of the more efficient material, the comparison may be done on the basis of the mineral uptake by the progenies at the whole palm tree level.

Since the FFB number of C2 and C3 palms is relatively high, they are also relatively large mineral sinks (Legros et al. 2006; Lamade et al. 2014). The resulting relatively high amounts of minerals stored in their FFB are ultimately exported from the plantation during harvesting. This might explain why their leaflet $\mathrm{K}$ concentrations were low compared to those of the C1 and C4 palms, which were less productive. However, further research should confirm the latter hypothesis.

High FFB production is not necessarily linked to a high optimum leaflet $\mathrm{K}$ concentration, as observed in the progenies that showed the highest bunch production (C3 \& C2) while displaying the lowest optimum leaflet K concentrations, whereas the progenies with the lowest bunch production (C1 \& C4) showed the highest optimum leaflet $\mathrm{K}$ concentrations. We can therefore hypothesize that leaflet $\mathrm{K}$ concentration is related to different allocations of $\mathrm{K}$ in the different oil palm tissues.

The seemingly inverse relation between a progeny's high yield and low leaflet $\mathrm{K}$ concentration does not mean that leaf analysis is an inaccurate tool for assessing nutrient deficiencies in oil palms, but does imply that there is room for fine-tuning (Dubos et al. 2019), and implies that genotypic differences in oil palm mineral use efficiency should be explored. Under equal $\mathrm{K}$ availability in the soil, contrasting leaflet $\mathrm{K}$ concentrations are linked to specific physiological mechanisms in oil palm progenies, such as photosynthesis and biochemical metabolism (soluble sugar and starch production), where minerals are used more or less efficiently (Lee et al. 2011, Chwill 2001\&2009, Jacquemard et al. 2010, Ollivier et al. 2013, Ollivier et al. 2017, Lamade et al. 2014, Legros et al. 2006 and Fabre et al. 2020). The high bunch and oil production observed in the palms of progeny C3, which had the lowest leaflet $\mathrm{K}$ concentration of all tested progenies, was probably the result of efficient $\mathrm{K}$ use, which might be linked to specific physiological traits between progenies (such as functional potassium channels in oil palm tissues). These hypotheses warrant further research. In hybrid cotton seedlings (Gossypium hirsutum) as in many other crops such as rice, sweet potato, oil palm, Fuqiang et al. (2010) and Zhang et al. (2007), Rengel and Damon (2008), Liu et al. 2009, Melvin et al. 2002, Prabowo et al. 2012 found significant genotypic differences in leaf $\mathrm{K}$ concentrations and $\mathrm{K}$ use efficiency.

Further studies are necessary to quantify mineral contents in different oil palm organs, in order to determine the true $\mathrm{K}$ and Mg uptake capacities and use efficiencies of the studied oil palm progenies.

\subsection{Oil palm progeny yield components and nutrient uptake}

We observed the highest bunch number in oil palms of Deli x La Mé origin and the lowest number in oil palms of Deli $\mathrm{x}$ Yangambi origin, which was also found by Cros et al. (2013) in Benin and Nouy et al. (1999) in Benin, Ivory Coast and Indonesia. In Indonesia, from 6 to 9 YAP, average bunch yields, produced by oil palms of the same progenies as in our study, amounted to $31.1,29.6,30.7$ and $32.5 \mathrm{t} \mathrm{ha}^{-1}$ year $^{-1}\left(230.2,219.6,227.5,240.6 \mathrm{~kg} \mathrm{palm}^{-1} \mathrm{year}^{-1}\right)$ for progenies C1, C2, C3 and C4, respectively, with no statistical differences between these yield figures (PIC 2012).

Despite that the oil palms in Indonesia were tested over a period that was just one year longer than in our experiment in Nigeria, we can safely assume that the higher bunch and oil production figures in Indonesia resulted from more favourable environmental conditions.

Unlike in Indonesia, in Nigeria we found significant differences in bunch production between the progenies. This confirms the well-known fact that oil palm production is determined by physiological processes brought about by both genetic and environmental factors. The palms of progeny $\mathrm{C} 3$ that produced the largest bunches in Nigeria had the smallest bunch sizes in Indonesia. On the other hand, the palms of progeny C4 (Delix Yangambi) had a significantly higher bunch weight than the palms of progenies C1 and C2 in both countries. Moreover, oil palms of Delix Yangambi origin are generally not able to fully express their production potential in less favourable environments (Nouy et al. 1999). The low bunch number per palm and the significantly higher male inflorescence numbers observed in our experiment for progeny C4 of Deli x Yangambiorigin (which is more susceptible to drought, Nouy et al. 1999; Legros et al. 2006), can therefore be linked to the relatively drier Nigerian environment compared to that of Indonesia and probably to differences in soil fertility. The drought period that occurred between 2015 and 2016 (El Niño phenomenon with more than 5 months of an inhabitual drought) was a factor that might have increased male inflorescence production in Nigeria.

As observed in our experiment, the high oil production found in progeny C3 in Nigeria is linked to the high bunch number and weight of C3 progeny oil palms (higher than that of all the other Deli x La Mé materials (C1, C2), as well as that of progeny C4 oil palms, which are of Delix Yangambi origin. As a result, these findings suggest that C3 progeny oil palms are interesting oil palm genetic material for oil palm production in Nigeria and - more generally - in all West African zones.

The lack of a $\mathrm{KCl}$ effect on the progenies' oil extraction rate (OER) implies that the latter parameter is influenced by genetic factors and therefore is the result of oil palm breeding (Durand-Gasselin et al. 2000, Cochard et al. 2005). 
In progeny $\mathrm{C} 3$, the average bunch weight increased by $0.35 \mathrm{~kg}_{\text {bunch }}{ }^{-1}$ between treatments $\mathrm{Mg} 0$ and $\mathrm{Mg} 1$ over the 5 to 8 YAP period, suggesting that Mg fertilization contributes to oil palm productivity in this progeny. However, given the antagonistic effect of $\mathrm{Mg}$ and $\mathrm{K}$ applications, $\mathrm{KCl}$ applications may inhibit the effects of $\mathrm{Mg}$ application. Despite the lack of $\mathrm{MgSO}_{4}$ effects on the evaluated parameters (apart from average bunch weight in progeny $\mathrm{C} 3$ ), the required $\mathrm{Mg}$ rates ought to depend on the balance between the optimum leaflet $\mathrm{K}$ and Mg concentrations (Doğan and Akinci 2011; Ciríaco da Silva et al. 2011) of the planting material used. The lack of a $\mathrm{MgSO}_{4}$ effect found in our study for most production parameters is frequently observed in oil palm fertilization experiments (Caliman et al. 1994, Tang et al. 2001 and Bonneau et al. 2018). It might be explained by the high amounts of exchangeable Mg in our experimental soil, which was (as generally observed in most ferralsols in tropical zones) even higher than the amount of exchangeable K (Supplementary table ST1), and need to be monitor to avoid excess Mg application in the field. Also in a factorial trial in Sumatra (Indonesia), in which different combinations of N,

$\mathrm{P}, \mathrm{K}$ and $\mathrm{Mg}$ rates were applied, Kusnu et al. (1996) only found a $\mathrm{Mg}$ effect on the bunch number in the third and fourth year of $\mathrm{MgSO}_{4}$ applications, but did not find any $\mathrm{MgSO}_{4}$ effect on the other yield components. This was probably linked to a lower $\mathrm{Mg}$ exchange capacity (exchangeable $\mathrm{Mg} 0.12 \mathrm{cmol} \mathrm{kg}^{-1}$ ) of their experimental soil compared to that of our experimental soil (exchangeable $\mathrm{Mg}: 0.37 \mathrm{cmol} \mathrm{kg}^{-1}$ between 0 and $20 \mathrm{~cm}$ ).

\section{Conclusion}

The four oil palm progenies considered in this study showed different yield potential. Our results showed that under Nigerian environmental conditions, oil palms of progeny C3 (Delix La Me) had a higher oil and bunch production than those of the other progenies with the lowest leaflet $\mathrm{K}$ concentrations. $\mathrm{C} 3$ oil palms thus appear to be an excellent planting material for the West African environment.

Potassium proved to be the main mineral involved in oil palm development, as well as in palm oil production. Our results also revealed specific optimum leaflet $\mathrm{K}$ concentration levels depending on the genetic origins of the oil palms in the Nigerian environment.

Recent clone development with more productive oil palm material on a global scale for new oil palm plantations enables the establishment of plantations with specific genotype, whereby oil palm growers will have tailor $\mathrm{K}$ fertilizer recommendations to the specific leaflet $\mathrm{K}$ concentrations of oil palm genotypes in a specific environment.

This study is a first step towards the selection of oil palm germplasm with improved K use efficiency. However, in order to confirm that palms of progeny $\mathrm{C} 3$ have the highest $\mathrm{K}$ use efficiency, the tested progenies' mineral ( $\mathrm{K}$ and $\mathrm{Mg}$ ) uptake capacities and use efficiencies need to be assessed on a whole plant level, rather than on the level of a single leaf.

\section{Declarations}

\section{Statements \& Declarations}

Olivier Dassou and Hervé Aholoukpè are employed by INRAB, where Adolphe Adjadohoun is the General Director. Reinout Impens is employed by Presco. Jean Ollivier, Xavier Bonneau and Albert Flori are employed by CIRAD. Benoît Cochard is Scientific Director at PalmElit, a subsidiary of CIRAD. All these companies have a collaboration partnership.

We declare that they have no known competing financial interests or personal relationships that could have appeared to influence the work reported in this paper.

\section{ACKNOWLEDGEMENTS}

The authors sincerely thank the Islamic Development Bank (IsDB) for providing a PhD scholarship to the first author, thanks to which the present research could be undertaken. We further thank INRAB, CIRAD, PRESCO and UGent for their technical and financial support.

\section{References}

1. Aholoukpè NSH, Amadji LG, Blavet D, Chotte JL, Deleporte P, Dubos B, Flori A, Jourdan C (2016) Effet de la gestion des feuilles d'élagage du palmier à huile sur le stock de carbone et les propriétés physico-chimiques du sol dans les palmeraies villageoises du Bénin. Biotechnol. Agron. Soc. Environ. 2016 20(2), 171-182.

2. Bonneau X, Impens R, Dassou O, Ogiamien F, VanDamme P (2018) Optimal fertilization for oil palm (Elaeis guineensis Jacq.) plantations: Conclusions from a Long-Term Fertiliser Trial in Nigeria. In: Tielkes E. (ed) Tropentag, Ghent "Global food security and food safety: The role of universities. Book of abstracts (on - line book of abstracts: http://www.tropentag.de/2018/proceedings). 594 p.

3. Bonneau X, Vandessel P, Buabeng M, Erhahuyi C (2014) Initial results of an oil palm planting density experiment in west Africa. OCL.

4. DPSciences,https://doi.org/10.1051/ocl/2017060. 21 (4) A 401.

5. Caliman JP, Daniel C, Tailliez B (1994) Oil palm mineral nutrition. Plantations, recherche, Développement, 3: 36-54.

6. Chwil S (2001) Wpływ dolistnego i doglebowego stosowania magnezu na wielkość i strukturę plonu pszenicy ozimej. Biul Magnezol 6 :118-124

7. Chwil S (2009) Oddziaływanie magnezu i azotu na cechy jakościowe plonu pszenicy ozimej. Ann Universitat Maria Curie Skłodowska Lublin-Polonia. 64 :61-66

8. CIGE (2013) Compréhension des interactions entre génotypes et environnements: Protocol for monitoring CIGE "field" trials. 24p. 
9. Ciríaco da Silva E, Custódio Nogueira RJM, Almeida da Silva M, Bandeira de Albuquerque M (2011) Drought Stress and Plant Nutrition. Plant Stress 5 (Special Issue 1), 32-41 @2011 Global Science Books. https://www.researchgate.net/publication/209959355

10. CIRAD USA 49 Montpellier, France

11. Cochard B, Amblard P, Durand-Gasselin T (2005) Oil palm genetic improvement and sustainable development. OCL VOL. 12 (2): $141-145$.

12. Corley RHV Tinker PB (2016) The oil palm. Blackwell Science Ltd, Oxford OX42DQ. 687 p.

13. Cros D, Flori A, Nodichao L, Omore A, Nouy B (2013) Differential response to water balance and bunch load generates diversity of bunch production profiles among oil palm. Tropical Plant Biol. 6 :26-36 DOI 10.1007/s12042-013-9116-2.

14. Dassou O, Nodichao L, Ollivier J, Impens R, Dubos B, Bonneau X, De Raïssac M, Durand-Gasselin T, Sinsin B \& Van Damme P (2018) Oil palm (Elaeis guineensis Jacq.) leaf $\mathrm{K}$ and $\mathrm{Mg}$ contents differ with progenies: implications and research needs. . In: Tielkes E. (ed) Tropentag, Ghent "Global food security and food safety: The role of universities. Book of abstracts (http://www.tropentag.de/2018/proceedings). 594 p.

15. Davidson L (1993) Management for efficiency, cost effective and productive oil palm plantations. In : Proc of 1991 Porim International Palm Oil Conference - Agriculture (Ed. By Basiron), 153-167. Palm Oil Res. Inst. Malaysia. Kuala Lumpur.

16. Doğan N, Akinci S (2011) Effects of water stress on the uptake of nutrients by bean seedlings (Phaseolus vulgaris L.). Fresenius Environmental Bulletin. FEB/ Vol 20/ No 8a/ 2011 - pages 2163 - 2173.

17. Dubos B, Baron V, Bonneau X, Dassou O, Flori A, Impens R, Ollivier J, Pardon L (2019) Precision agriculture in oil palm plantations : diagnostic tools for sustainable $n$ and k nutrient supply. OCL 26: 5. Published by EDP Sciences, https://doi.org/10.1051/ocl/2019001

18. Dubos B, Baron V, Bonneau X, Flori A, Ollivier J (2017) High soil calcium saturation limits use of leaf potassium diagnosis when kcl is applied in oil palm plantations. Experimental agriculture, Volume 54, Issue 5, pp. 794 - 804. DOI: https://doi.org/10.1017/S0014479717000473.

19. Dubos B, Herna'n W, Jesu's A, Lo'pez E, Ollivier J (2010) Potassium uptake and storage in oil palm organs: the role of chlorine and the influence of soil characteristics in the Magdalena valley, Colombia. Nutr Cycl Agroecosyst. DOI 10.1007/s10705-010-9389-x.

20. Dufrène E, Ochs R, Saugier B (1990) Photosynthèse et productivité du palmier à huile en liaison avec les facteurs climatiques. Oléagineux, Vol. 45 , ${ }^{\circ} 8-9$.

21. Durand-Gasselin T, de Franqueville H, Breton F, Amblard P, Jacquemard J-C, Syaputra I, Cochard B, Louise C, Nouy B (2011) Breeding for sustainable palm oil. Int. Semin. Breed. Sustain oil palm. 1781193.

22. Durand-Gasselin T, Blangy L, Picasso C, De Franqueville H, Breton F, Amblard P, Cochard B, Louise C, Nouy B (2010) Sélection du palmier à huile pour une huile de palme durable et responsabilité sociale. OCL. Vol 17 Nº6. $385-392$.

23. Durand-Gasselin T, Hayun S, Jacquemard J-C, Indra S, Adje I, Flori A,Nouy B (2006) Palm oil yield potential of oil palm (Elaeis guineensis) seeds developed in a network by Cirad and its partners. In : International Workshop int the Yield Potential in the oil palm, Phuket, Thailand 27-28 November 2006. ISOPB. s.I. : s.n., 15 p. ISOPB International Workshop on the Yield Potential in the oil palm, Phuket, Thaïlande, 27 Novembre $2006 / 28$ Novembre 2006.

24. Durand-Gasselin T, Kouame R, Cochard B, Adon B, Amblard P (2000) Diffusion variétale du palmier à huile (Elaeis guineensis Jacq.). Oléagineux, Corps Gras, Lipides, 7 (2): 207-14.

25. Fabre D, Dingkuhn M, Yin X, Clement-Vidal A, Roques S, Soutiras A, Luquet D (2020) Genotypique variation in sources and sink traits affects the response of photosynthesis and growth to elevated atmospheric C02. Plant Cell and Environment. $15 p$.

26. Fuqiang Y, Gangwei W, Zhiyong Z, Egrinya Eneji A, Liusheng D, Zhaohu L, Xiaoli T (2010) Genotypic variations in potassium uptake and utilization in cotton, Journal of Plant Nutrition, 34:1, 83-97, DOI: 10.1080/01904167.2011.531361 Fairhurst, T. 1996. Management of nutrients for efficient use in smallholder oil palm plantations. PhD, Departement of biological Sciences, Wye Collège, London.211p.

27. Gerendás J, Führs H (2013) The significance of magnesium for crop quality. Plant Soil. 368 :101-128. D0I 10.1007/s11104-012-1555-2. 28p.

28. Goh KJ, Teo CB, Chew PS, Chiu SB (1999) Fertiliser management in oil palm : Agronomic principles and field practices. Paper presented at "Fertilizer Management For Oil palm Plantations", 20-21 September 1999, Sandakan, Sabah, Malaysia. Organised by ISP, Sabah North-East Branch.

29. IRHO-CIRAD-IGK-9 (1996) Instructions générales Analyses de regimes (General instructions for bunch analysis). Paris: IRHO.

30. Jacquemard JC, Ollivier J, Erwanda Suryana E, Permadi P (2010) Mineral nutrition and its genetic signature in oil palm (Elaeis guineensis Jacq.): a possible panorama for high yielding materials at low fertiliser cost.

31. Kusnu M, Siahaan MM, Poeloengan Z (1996) Effects of N, P, K and Mg fertilizer on the growth and yield of oil palm on Typic Paleudult. In: Sustainability of oil palm plantations. Agronomic and Environmental perspectives. Kuala Lumpur, 27-28 September. ISOPA, PORIM, 14p.

32. Lamade E, Ollivier J, Rozier-Abouab TH, Gérardeaux E (2014) Occurrence of potassium location in oil palm tissues with reserve sugars: consequences for oil palm K status determination. IOPC conference, 17-19 June, Bali Convention Center, oral communication.

33. Lee CT, Zaharah AR, Mohamed Hanafi M, Che Fauziah M, Ishak Shahkhirat N, Tan CC Mohd Salihuddin MY (2014) Rachis nutrient concentrations of different oil palm genotypes as affected by irrigation and terrain. Journal of oil palm Research. Vol 26 (2) June 2014, 146-153.

34. Lee C, Rahman ZA, Hanafi Musa M, Shahkhirat Norizan M, Tan CC (2011) Leaf nutrient concentrations in oil palm as affected by genotypes, irrigation and terrain. Journal of oil palm \& The Environment, 2:38-47 doi:10.5366/jope.2011.05

35. Legros S, Mialet-serra I, Caliman JP, Siregar FA, Clement-Vidal A, Widiastuti L, Jourdan C, Dingkuhn M (2006) Carbohydrates reserves in 9 years old oil palm: nature, distribution and seasonal changes. IOPC- Optimum use of resources: Challenges and opportunities for sustainable oil palm developpement, Bali.

36. Liu G, Li Y, Porterfield DM (2009) Genotypic Differences in Potassium Nutrition in Lowland Rice Hybrids, Communications in Soil Science and Plant Analysis, 40:11-12, 1803-1821, DOI: 10.1080/00103620902896704 To link to this article: http://dx.doi.org/10.1080/00103620902896704 
37. Melvin SG, Guoquan L, Weijun Z, (2002) Genotypic variation for potassium uptake and utilization efficiency in sweet potato (Ipomoea batatas L.). Field crop research. http://www.paper.edu.cn

38. Nodichao L, Aké S, Jourdan C, (2008) Développement du système racinaire chez le palmier à huile selon l'origine génétique et le régime hydro-potassique du sol. Agronomie Africaine, $203: 277-289$.

39. Nouy B, Baudouin L, Djégui N, Omoré A (1999) Oil palm under limiting water supply conditions. Plantations, Recherche, Développement. $6: 31-45$.

40. Ochs R (1985) Stratégie de mise en œuvre du contrôle nutritionnel des plantes pérennes : Gestion de la nutrition minérale et programmation des fumures. Oléagineux, Vol. 40, N 12.

41. Omont $\mathrm{H}$ (2010) Contribution à la production d’huile de palme au développement durable : problématique générale et controverses. OCL, Vol 17 N6.

42. Ollivier J, Flori A, Cochard B, Amblards P, Turnbull N, Syahputra I, Suryana E, Lubis Z, Surya E, Sihombing E, Durand - Gasselin T (2017) Genetic variation in nutrient uptake and nutrient use efficiency of oil palm. Journal of plant nutrition. 2017, VOL. 40, NO. 4, 558-573.

http://dx.doi.org/10.1080/01904167.2016.1262415.

43. Ollivier J, Lamade E, Dubos B, Erwanda Surya P, Permadi SE, Flori A, Cochard B, Jacquemard C (2013) Hacia un diagnostic nutricional preciso para la palma de aceite, teniendo en cuenta el origen del material de siembra. Palmas 34(1), 203-220. Towards an accurate nutritional diagnosis for oil palm taking into account the origin.

44. Pinta (1973) Méthode de référence pour la détermination des éléments minéraux dans les végétaux (Reference methods for the determination of mineral elements in plants). Oleagineux, 28-87-92.

45. PIC (2012) Rapport du Programme d'Intérêt Commun (PIC) entre INRAB - CIRAD et PalmElit : Bilan exercice 2011 - perspective 2012.

46. PIC (2011) Rapport du Programme d'Intérêt Commun (PIC) entre INRAB - CIRAD et PalmElit : Bilan exercice 2010 - perspective 2011.

47. Prabowo NE, Lubis T, Fairhurst T, Foster HL, Nafisah EN (2012) Practical use of oil palm nutrient physiological efficiency with regard to nutrient recovery and Agronomic efficiencies at different Sumatran Sites. In: 2002 International oil palm Conference and Exhibition. IOPRI, Bali, Indonesia, 8-12 July 2002, $9 p$.

48. Rengel Z, Damon PM (2008) Crops and genotypes differ in efficiency of potassium uptake and use. Copyright Physiologia Plantarum, ISSN $0031-9317$. doi: 10.1111/j.1399-3054.2008.01079.x

49. R 3.6.0 for Windows, $32 / 64$ bit

50. Tang MK, Nazeeb M, Loong SG (2001) Proceedings of the PIPOC 2001 International Palm Oil Congress. Malaysian Palm Oil Board, Kuala Lumpur, pp 261-271

51. Tarmizi AM, Mohd TD (2006) Nutrient demands of Tenera oil palm planted on Inland soils of Malaysia. Journal of oil palm Research Vol. 18 June 2006 p. 204-209.

52. Teoh KC Chew PS (1988b) Use of rachis analysis as an Indicator of K nutrient status in oil palm. In: Hj Hassan, H.A.H., Chew, P.S., Wood, B.J., and Pushparajah, E., (eds.) International Oil Palm/Palm Oil Conferences: Progress and Prospects.

53. Webb M (2009) A conceptual framework for determining economically optimal fertiliser use in oil palm plantations with factorial fertiliser trials. Nutrient Cycling in Agroecosystems. $200983: 163-178$.

54. XLSAT, Version 2018-7, www.xlstat.com

55. Yanbo J, Xiaoe Y, Ejazul I, Ying F (2008) Effects of Potassium Deficiency on Chloroplast Ultrastructure and Chlorophyll Fluorescence in Inefficient and Efficient Genotypes of Rice. Journal of Plant Nutrition, 31:12, 2105-2118, DOI: 10.1080/01904160802459625

56. Zhang ZY, Tian XL, Duan LS, Wang BM, He ZP, Li ZH (2007) Differential responses of conventional and Bt-transgenic cotton (Gossypium hirsutum L.) to potassium deficiency. Journal of Plant Nutrition 30: 659-670.

\section{Tables}

Table 1

Bunch number, average bunch weight $(\mathrm{kg})$ and number of male inflorescences per oil palm of different oil palm progenies in response to $3 \mathrm{KCl}$ treatments 
Number of bunches per palm

$\begin{array}{ll} & \text { K } \\ \text { Progels } & \\ \text { levies } & \end{array}$
Average bunch weight $(\mathrm{Kg})$

Average

5 years 6 years 7 years 8 years
$5-8$

old

$\begin{array}{llllll}\text { KO } & 21.5 a & 7.55 a & 15.4 a & 11.33 b\end{array}$

K1

C1

$$
K 2
$$

K2

21.9

8.21

$23.2 a$

$8.27 a$

$\begin{array}{ll}15.1 a & 12.1 \\ 15.0 a & 12.3\end{array}$

12.19
$a b$
$12.38 a$

$12.38 a$

14.
$6.0 b$
14.3
$5.8 a b$
14.7
6.3

$14.0 \pm 4.95 a \quad 6.76 a-775 a \quad 9.0 a-7.17 \pm 0$

Number of male in

\begin{tabular}{|c|c|c|c|c|c|c|c|c|c|c|c|c|c|}
\hline & & $22.2 \mathrm{~A}$ & $8.01 \mathrm{BC}$ & $15.2 \mathrm{~A}$ & $12.0 \mathrm{~B}$ & $\begin{array}{l}14.4 \pm \\
6.0 A\end{array}$ & $5.0 \mathrm{~B}$ & $6.89 \mathrm{~A}$ & $7.98 \mathrm{C}$ & $9.28 \mathrm{C}$ & $\begin{array}{l}7.3 \pm \\
1.8 D\end{array}$ & $0.83 \mathrm{C}$ & 11.1 D \\
\hline & KO & $20.1 a$ & $8.12 a$ & $15.0 \mathrm{a}$ & $12.9 a$ & $\begin{array}{l}14.1 \pm \\
5.0 \mathrm{a}\end{array}$ & $4.88 a$ & $6.06 b$ & $8.41 a$ & $9.9 a$ & $\begin{array}{l}7.3 \pm \\
2.3 b\end{array}$ & $4.03 a$ & $12.4 a b$ \\
\hline & K1 & $20.8 a$ & $8.52 a$ & $15.0 \mathrm{a}$ & $12.9 a$ & $\begin{array}{l}14.3 \pm \\
5.1 a\end{array}$ & $5.11 a$ & $6.70 a$ & $9.04 a$ & $10.6 a$ & $\begin{array}{l}7.9 \pm \\
2.4 a\end{array}$ & $3.27 a$ & $11.7 b$ \\
\hline $\mathrm{C} 2$ & $K 2$ & $20.8 a$ & $8.30 a$ & $15.6 a$ & $13.12 a$ & $\begin{array}{l}14.4 \pm \\
5.2 a\end{array}$ & $5.05 a$ & $6.57 a b$ & $8.82 a$ & $10.6 a$ & $\begin{array}{l}7.8 \pm \\
2.4 a b\end{array}$ & $3.93 a$ & $12.6 a$ \\
\hline
\end{tabular}

\begin{tabular}{|c|c|c|c|c|c|c|c|c|c|c|c|c|c|}
\hline & & $20.6 \mathrm{~B}$ & $8.31 \mathrm{~B}$ & $15.2 \mathrm{~A}$ & $13.0 \mathrm{~A}$ & $\begin{array}{l}14.3 \pm \\
5.1 \mathrm{~A}\end{array}$ & $5.01 \mathrm{~B}$ & $6.45 \mathrm{~B}$ & $8.76 \mathrm{~B}$ & $10.4 \mathrm{~B}$ & $\begin{array}{l}7.7 \pm \\
2.4 \mathrm{C}\end{array}$ & $3.7 \mathrm{~B}$ & $12.2 \mathrm{C}$ \\
\hline \multirow{3}{*}{ C3 } & KO & $20.4 a$ & $7.57 a$ & $12.9 a$ & $13.46 a$ & $\begin{array}{l}13.6 \pm \\
5.2 a\end{array}$ & $5.82 b$ & $6.43 b$ & $10.4 b$ & $11.3 b$ & $\begin{array}{l}8.5 \pm \\
2.8 b\end{array}$ & $3.79 a$ & $15.0 \mathrm{a}$ \\
\hline & $K 1$ & $20.7 a$ & $7.88 a$ & $12.8 a$ & $13.16 a$ & $\begin{array}{l}13.64 \pm \\
5.2 a\end{array}$ & $6.08 a b$ & $6.84 b$ & $10.6 a b$ & $12.1 a$ & $\begin{array}{l}8.9 \pm \\
2.9 b\end{array}$ & $4.14 a$ & $14.5 a$ \\
\hline & $K 2$ & $24.4 a$ & $7.49 a$ & $12.7 a$ & $13.76 a$ & $\begin{array}{l}14.59 \pm \\
7.1 a\end{array}$ & $6.35 a$ & $7.49 a$ & $11.1 \mathrm{a}$ & $12.4 a$ & $\begin{array}{l}9.3 \pm \\
2.9 a\end{array}$ & $4.35 a$ & $14.8 a$ \\
\hline
\end{tabular}

\begin{tabular}{|c|c|c|c|c|c|c|c|c|c|c|c|c|c|}
\hline & & $20.5 \mathrm{~B}$ & $7.65 \mathrm{C}$ & $12.8 \mathrm{~B}$ & $13.5 \mathrm{~A}$ & $\begin{array}{l}13.6 \pm \\
5.3 B\end{array}$ & $6.08 \mathrm{~A}$ & $6.92 \mathrm{~A}$ & $10.7 \mathrm{~A}$ & $11.9 \mathrm{~A}$ & $\begin{array}{l}8.9 \pm \\
2.8 A\end{array}$ & $4.1 \mathrm{~B}$ & $14.8 \mathrm{~B}$ \\
\hline \multirow{3}{*}{$\mathrm{C} 4$} & KO & $14.7 a$ & $8.95 a$ & $12.8 a$ & $10.2 a$ & $\begin{array}{l}11.3 \pm \\
2.6 a\end{array}$ & $5.6 b$ & $5.73 b$ & $7.6 b$ & $10.6 b$ & $\begin{array}{l}7.4 \pm \\
2.3 b\end{array}$ & $10.4 b$ & $16.1 a$ \\
\hline & $K 1$ & $14.2 a$ & $9.46 a$ & $12.7 a$ & $9.89 a b$ & $\begin{array}{l}11.66 \pm \\
2.3 a\end{array}$ & $6.11 a$ & $6.68 a$ & $8.31 a$ & $12.3 a$ & $\begin{array}{l}8.4 \pm \\
2.8 a\end{array}$ & $12.8 a$ & $15.9 a$ \\
\hline & $K 2$ & $14.3 a$ & $8.60 a$ & $13.1 \mathrm{a}$ & $9.15 b$ & $\begin{array}{l}11.29 \pm \\
2.8 a\end{array}$ & $6.35 a$ & $6.47 a$ & $8.31 a$ & $12.7 a$ & $\begin{array}{l}8.5 \pm \\
3.0 a\end{array}$ & $10.9 b$ & $15.9 a$ \\
\hline
\end{tabular}

\begin{tabular}{|c|c|c|c|c|c|c|c|c|c|c|c|}
\hline $14.4 \mathrm{C}$ & $9.00 \mathrm{~A}$ & $12.87 \mathrm{~B}$ & $9.75 \mathrm{C}$ & $\begin{array}{l}11.4 \pm \\
2.5 C\end{array}$ & $6.02 \mathrm{~A}$ & $6.29 \mathrm{~B}$ & $8.07 \mathrm{C}$ & $11.8 \mathrm{~A}$ & $\begin{array}{l}8.1 \pm \\
2.7 A\end{array}$ & $11.4 \mathrm{~A}$ & $16.0 \mathrm{~A}$ \\
\hline
\end{tabular}

\begin{tabular}{|c|c|c|c|c|c|c|c|c|c|c|c|c|}
\hline Average & 19.43 & 8.24 & 14.02 & 12.03 & $\begin{array}{l}13.1 \pm \\
5.6\end{array}$ & 5.53 & 6.64 & 8.9 & 10.8 & $\begin{array}{l}8.0 \pm \\
2.4\end{array}$ & 5.01 & 13.5 \\
\hline$P$ & $<0.0001$ & $<0.0001$ & $<0.0001$ & $<0.0001$ & & $<0.0001$ & $<0.0001$ & $<0.0001$ & $<0.0001$ & & $<0.0001$ & $<0.000^{\prime}$ \\
\hline
\end{tabular}

Lower-case letters $(\mathrm{a}-\mathrm{d})$ indicate differences $(p<0.01)$ revealed by the Tukey test in the yield parameters between the 3 different $\mathrm{KCl}$ treatments for each progeny and for each production year.

Upper-case letters $(A-D)$ indicate differences $(p<0.0001)$ in yield parameter averages for all $\mathrm{KCl}$ treatments between progenies revealed by the Tukey test for each production year.

For each parameter, the last column presents the average production of the four years (5-8 YAP) \pm standard deviation.

Table 2

Average crude palm oil production parameters of the four oil palm progenies. 


\begin{tabular}{|c|c|c|c|c|c|}
\hline Progeny & $\begin{array}{l}\text { FFB }: 5-8 \text { years } \\
\left(\text { t ha }^{-1} \text { year }^{-1}\right)\end{array}$ & $\begin{array}{l}\text { OER }{ }_{\text {Lab }} \\
(\%)\end{array}$ & $\begin{array}{l}\mathrm{OER}_{\text {mill }} \\
(\%)\end{array}$ & $\begin{array}{l}\mathrm{CPO}_{\text {Lab }}: 5-8 \text { years } \\
\left(\mathrm{t} \mathrm{ha}^{-1} \text { year }^{-1}\right)\end{array}$ & $\begin{array}{l}\mathrm{CPO}_{\text {mill }}: 5-8 \text { years } \\
\left(\mathrm{t} \mathrm{ha}^{-1} \text { year }^{-1}\right)\end{array}$ \\
\hline C1 & $13.10 \mathrm{c}$ & $32.10 \mathrm{bc}$ & 27.45 bc & $4.21 \mathrm{c}$ & $3.60 \mathrm{c}$ \\
\hline C2 & $14.20 \mathrm{~b}$ & $32.46 \mathrm{ab}$ & $27.75 a b$ & $4.62 \mathrm{~b}$ & $3.95 b$ \\
\hline C3 & $15.80 \mathrm{a}$ & $32.74 \mathrm{a}$ & $27.99 \mathrm{a}$ & $5.16 \mathrm{a}$ & $4.41 \mathrm{a}$ \\
\hline C4 & $12.20 \mathrm{~d}$ & $31.65 \mathrm{c}$ & $27.06 \mathrm{c}$ & $3.78 \mathrm{~d}$ & $3.23 \mathrm{~d}$ \\
\hline
\end{tabular}

FFB: fresh fruit bunch, $\mathrm{OER}_{\text {Lab }}$ : oil extraction rate in the laboratory, $\mathrm{OER}_{\text {mill }}$ : oil extraction rate in the mill, $\mathrm{CPO}_{\text {Lab }}$ : $\mathrm{Crude}$ palm oil in the laboratory, $\mathrm{CPO}_{\text {mill }}$ : crude palm oil in the mill.

Production data are the averages of the last four years $(5-8)$ of observation. $a, b, c$ and d indicate the differences in parameters between progenies revealed by the Tukey test.

\section{Figures}

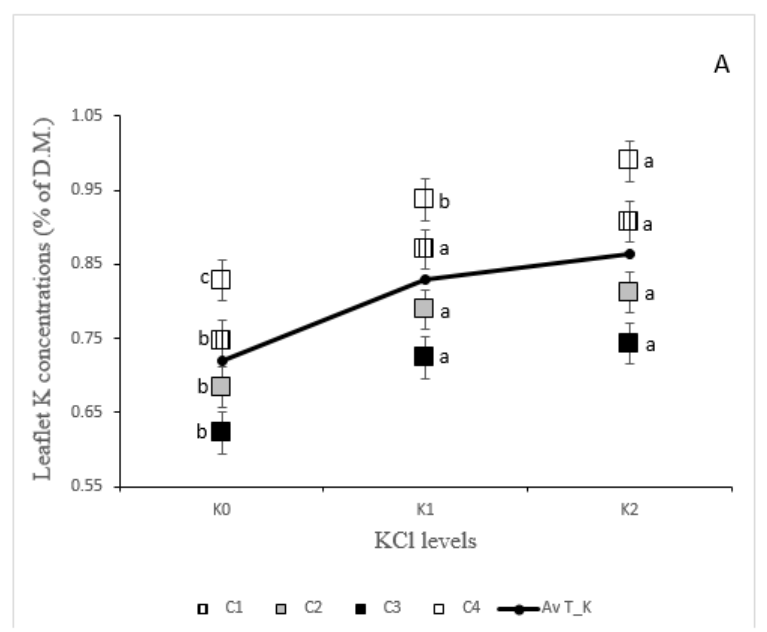

A

B
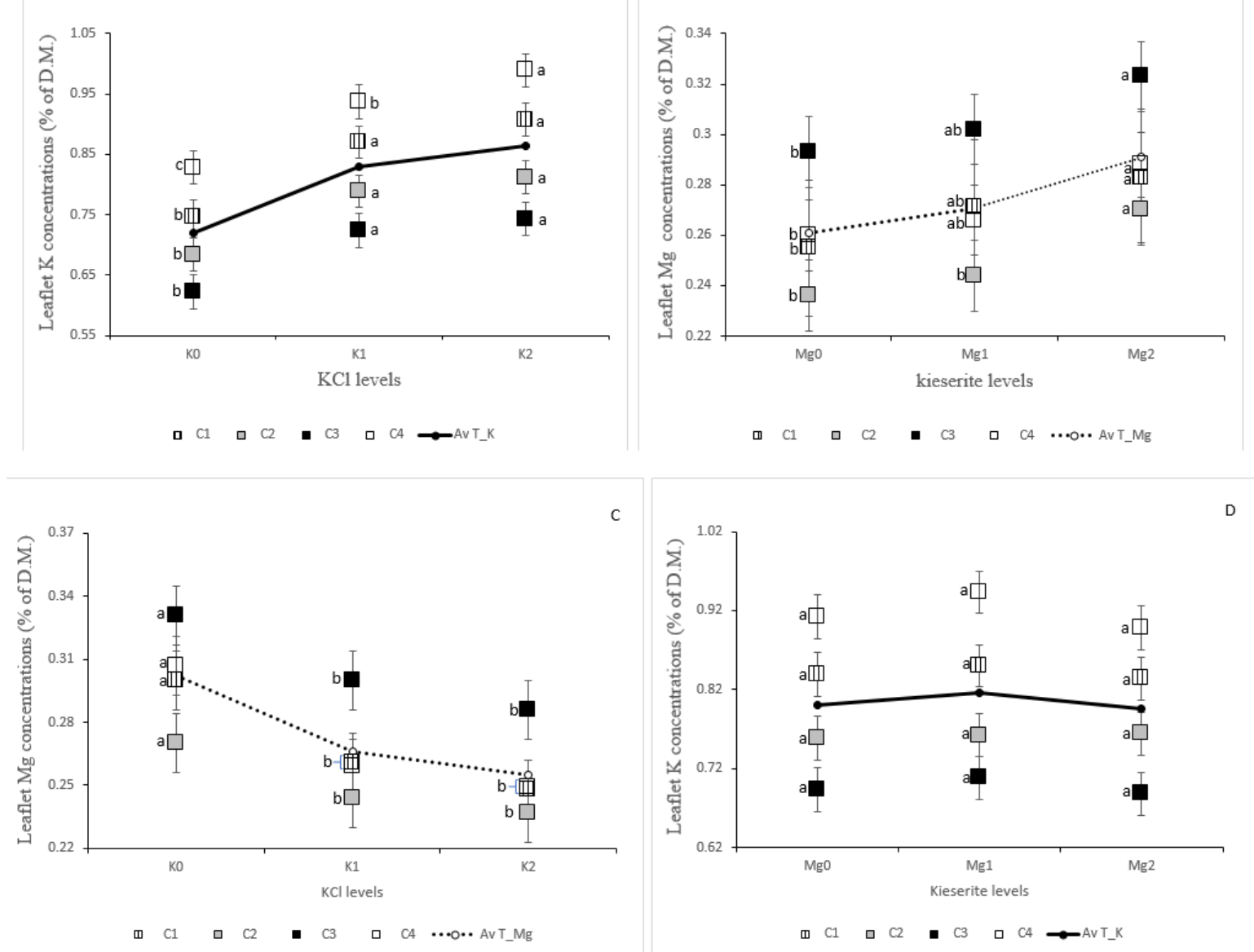

Figure 1

Oil palm progeny average leaflet nutrient (K and Mg) concentrations over the 2016-2018 period (5 to 7 YAP) at different KCl (A) and MgSO4 (B) application rates and the effect of $\mathrm{KCl}$ on leaflet $\mathrm{Mg}$ concentrations (C), as well as of $\mathrm{MgSO} 4$ on leaflet $\mathrm{K}$ concentrations (D) Av T_K and Av T_Mg are respectively, average leaflet $\mathrm{K}$ and leaflet $\mathrm{Mg}$ concentrations for all progenies (C1, C2, C3 and C4) in response to different $\mathrm{KCl}$ and $\mathrm{MgSO} 4$ rates Letters a, b and $\mathrm{c}$ indicate significant $(\mathrm{P}<0.0001)$ differences in progeny leaflet concentrations revealed by the Tukey test between the different $\mathrm{KCl}(\mathrm{A})$ and $\mathrm{MgSO} 4(\mathrm{~B})$ application rates 


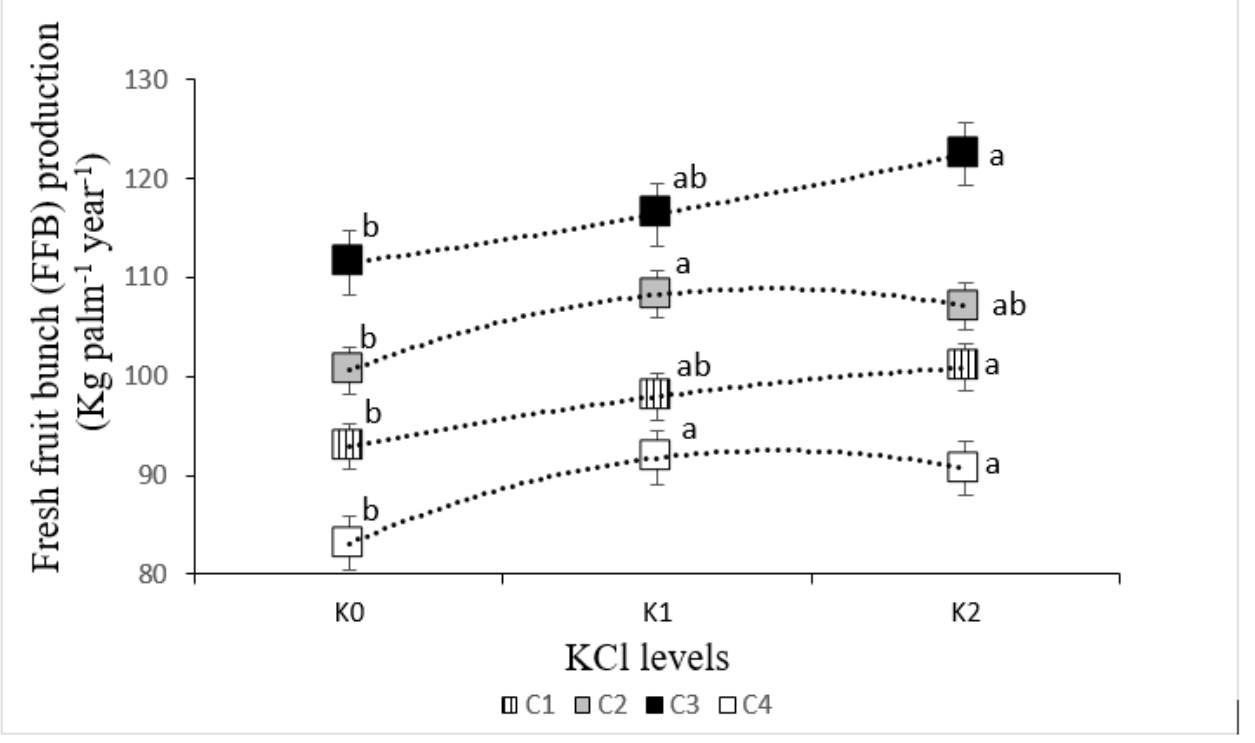

\section{Figure 2}

Average annual fresh fruit bunch yields $(\mathrm{kg})$ per palm of the different oil palm progenies from 5 to 8 YAP (four consecutive harvesting years) according to 3 $\mathrm{KCl}$ application rates Letters a and $\mathrm{b}$ indicate significant $(\mathrm{p} \leq 0.05)$ differences in FFB production between 4 oil palm progenies revealed by the Tukey test from 5 to $8 \mathrm{YAP}$ for $3 \mathrm{KCl}$ application rates.

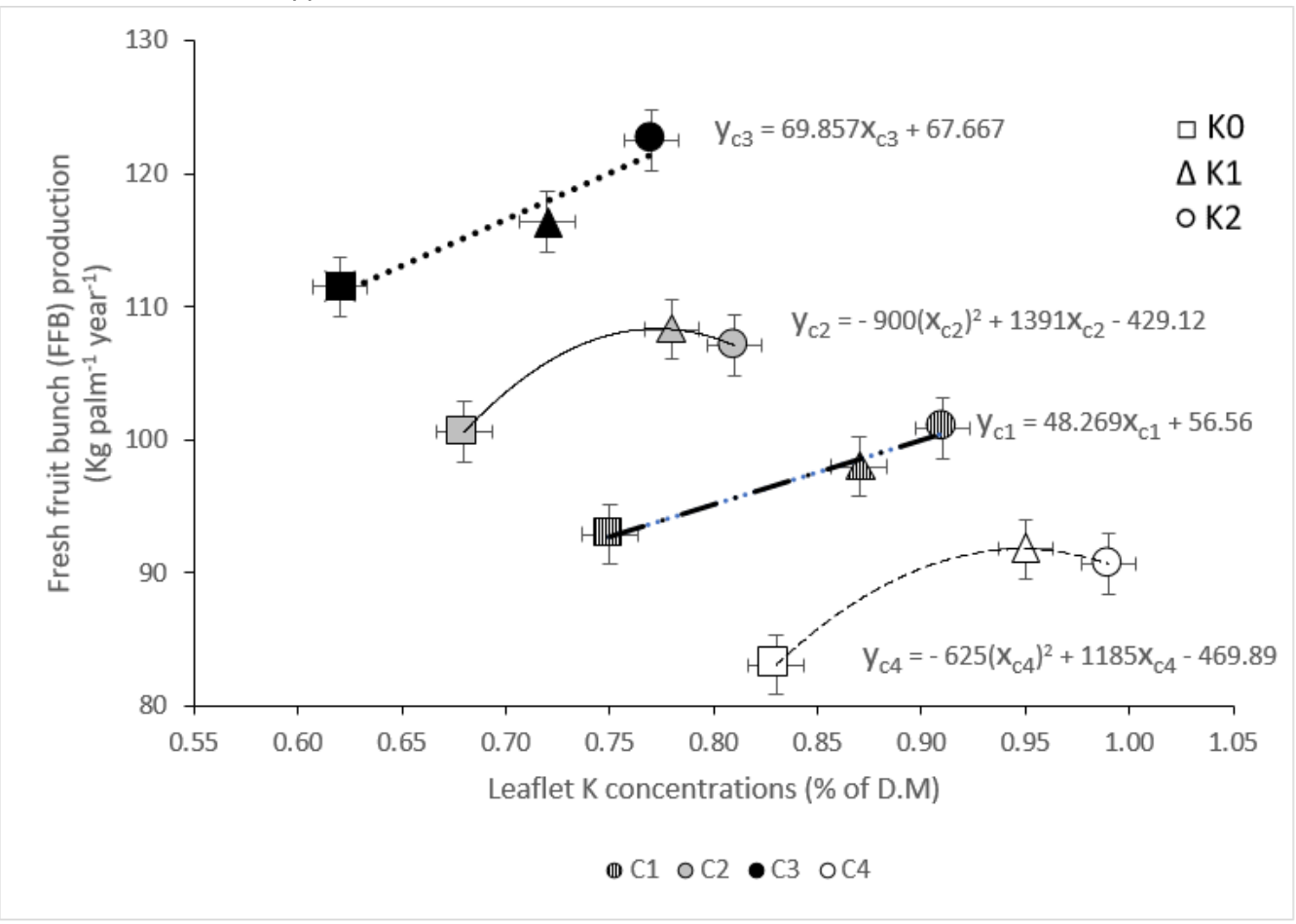

\section{Figure 3}

Average annual fresh fruit bunch yields $(\mathrm{kg})$ per palm of the different oil palm progenies from 5 to 8 YAP (four consecutive harvesting years) according to their leaflet $\mathrm{K}$ concentrations between 5 to 7 YAP y: fresh fruit bunch (FFB) production, $\mathrm{x}$ : leaflet $\mathrm{K}$ concentrations for the different progenies (C1, C2, C3 and C4), $\mathrm{K}$ levels (K0, K1 and K2), E1, E2, E3 and E4: Equation of FFB production determination on the basis of each progeny leaflet K concentrations.

\section{Supplementary Files}

This is a list of supplementary files associated with this preprint. Click to download. 
- Supplementarymaterials.docx

Page 13/13 